\title{
A Rare Cause of Acute Pancreatitis: Unexpected Travel of the Biliary Catheter
}

\author{
Hüseyin Özgür Aytaç, Kenan Çalışkan
}

Department of General Surgery, Başkent University Faculty of Medicine, Adana, Turkey

\section{To the Editor,}

Biliary leakage is an important complication that occurs after cholecystectomy (1). Unless uncomplicated, it generally closes spontaneously if there is no distal obstruction (2). The therapeutic endoscopic retrograde cholangiopancreatography (ERCP) procedure is helpful in the clearance of biliary flow and lowering the biliary pressure (3). In case of insufficiency of the ERCP procedure, percutaneous biliary drainage maneuvers can help to control biliary fistulas or save time for surgery $(4,5)$. We present a case of bile leakage which occurred after laparoscopic cholecystectomy, where we encountered an interesting cause of acute pancreatitis.

A 32 year-old woman who underwent a laparoscopic cholecystectomy two weeks previously was referred to us with a drain placed in the operation wound, suggesting bile leakage. Physical examination revealed disseminated tenderness of the abdomen. Transaminase, amylase and lipase levels were normal. Computed tomography scan showed a $10 \mathrm{~cm}$ fluid collection in the sub-hepatic area. We followed her up for two weeks with the drainage of $200 \mathrm{~mL}$ of bile daily. A magnetic resonance cholangiopancreatography imaging was obtained showing some sludge and stone of $22 \mathrm{~mm}$ in the distal common hepatic duct (CHD). An ERCP was applied, where the pancreatic duct was found to be widened, but CHD could not be cannulated. An $8 \mathrm{~F}$ pigtail-locked percutaneous internal-external biliary drainage catheter (Flexima ${ }^{\circledR}$ Drainage Catheters, Boston Scientific; Natick, MA, USA) was placed and a prominent leakage from the cystic duct stump was demonstrated in cholangiography (Figure 1a). Fluid collection diminished by the $24^{\text {th }}$ day. During the second catheter cholangiography, some small stones were pushed into the duodenum by a balloon catheter. One big stone, which remained in place, was ex- tracted on the following day, by a successful ERCP procedure performed with the guidance of a biliary catheter (Figure 1b). Oral feeding was never paused. The intra-abdominal drainage
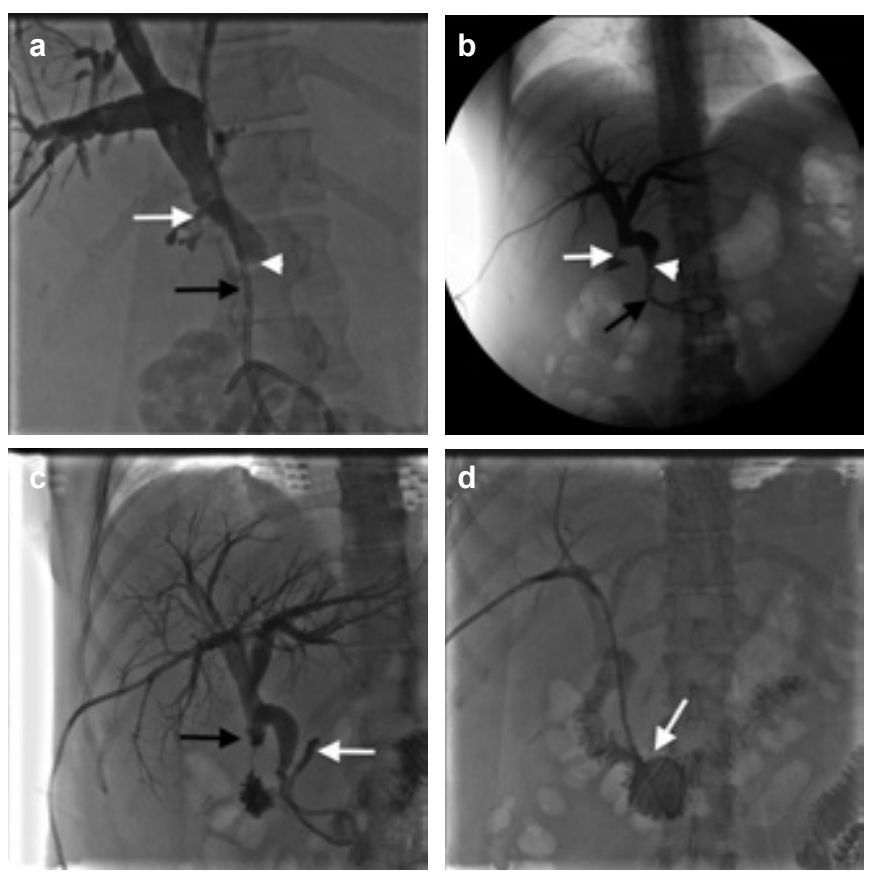

FIG. 1. a, b. Cholangiography film obtained after the internal-external biliary drainage catheter is placed. Biliary leakage at the level of cystic duct stump (white arrow). Image of stone or sludge at the level of distal common bile duct (CBD) (white arrow head). External-internal biliary drainage catheter (black arrow) (a), ERCP image after the sludge at the level of distal CBD is cleared (white arrow head). Biliary leakage at the level of cystic duct stump (white arrow). Internal-external biliary drainage catheter (black arrow) (b), Cholangiography obtained after the patient presented with acute pancreatitis, demonstrating the migration of the tail of the internal-external biliary drainage catheter into the duct of Virsung (white arrow). Leakage persists at the level of cystic duct stump (black arrow) (c), after repositioning of the catheter (arrow) (d). 
catheter was removed and the patient was discharged on the $33^{\text {rd }}$ day with the biliary catheter. On the $15^{\text {th }}$ day of discharge, she presented with abdominal pain. Laboratory assessment demonstrated a marked elevation in serum amylase and lipase levels. She was re-hospitalized for acute pancreatitis. A control catheter cholangiogram showed an unexpected migration of the catheter into the duct of Virsung, which clarified the etiology of acute pancreatitis (Figure 1c). The catheter was repositioned (Figure 1d) and she was discharged on the following day. A spontaneous closure of the leakage was observed on a consequent catheter cholangiogram obtained a week later. The biliary catheter was removed and the patient visited the outpatient clinic without any complaint after three weeks.

Biliary drainage catheters are loyal assistants of surgeons. Unless hemobilia or bilhemia occurs, they serve as lifeguards in biliary problems, whereas catheters are foreign bodies and can sometimes make matters worse. When a patient being followed-up with a percutaneous biliary catheter exhibits a state of sudden acute pancreatitis, besides other common reasons, catheter migration through the duct of Virsung must be kept in mind. This case seems to be the first in the literature demonstrating a biliary catheter responsible for acute pancreatitis by migrating into the duct of Virsung.

\section{Ethics Committee Approval: N/A.}

Informed Consent: Written informed consent was obtained from patient who participated in this study.

Peer-review: Externally peer-reviewed.
Author contributions: Concept - H.Ö.A., K.Ç.; Design - H.Ö.A., K.Ç.; Supervision - K.Ç., H.Ö.A.; Resource - H.Ö.A., K.Ç.; Materials - H.Ö.A., K.Ç.; Data Collection \&/or Processing - K.Ç., H.Ö.A.; Analysis \&/or Interpretation - K.Ç., H.Ö.A.; Literature Search H.Ö.A.; Writing - H.Ö.A.; Critical Reviews - K.Ç.

Conflict of Interest: No conflict of interest was declared by the authors.

Financial Disclosure: The authors declared that this study has received no financial support.

\section{REFERENCES}

1. Grbas H, Kunisek L, Zelić M, Petrosić N, Cepić I, Pirjavec A, et al. Outcome evaluation of 10,317 laparoscopic cholecystectomies: a 17-year experience at a single center. Hepatogastroenterology 2012;60:1873-6.

2. Ahmad F, Saunders R, Lloyd G, Lloyd D, Robertson G. An algorithm for the management of bile leak following laparoscopic cholecystectomy. Ann R Coll Surg Engl 2007;89:51. [CrossRef]

3. Singh V, Singh G, Verma GR, Gupta R. Endoscopic management of postcholecystectomy biliary leakage. Hepatobiliary Pancreat Dis Int 2010;9:409-13.

4. Thompson CM, Saad NE, Quazi RR, Darcy MD, Picus DD, Menias CO. Management of iatrogenic bile duct injuries: role of the interventional radiologist. Radiographics 2013;33:117-34. [CrossRef]

5. De Jong E, Moelker A, Leertouwer T, Spronk S, Van Dijk M, van Eijck C. Percutaneous transhepatic biliary drainage in patients with postsurgical bile leakage and nondilated intrahepatic bile ducts. Dig Surg 2012;30:444-50. [CrossRef] 